\title{
MOLECULAR TAPHONOMY OF PLANT TISSUE AT THE MIOCENE CLARKIA SITE, NORTHERN IDAHO
}

LOGAN, Graham, Organic Geochemistry Unit, School of Chemistry, and Dept. of Geology, University of Bristol, Bristol BS8 1RJ, United Kingdom.

The 17-20 million year old Miocene locality at Clarkia, northern Idaho, has become renowned as the first site to yield amplifiable DNA of geological age. This discovery has opened up the possibility of phylogenetic studies on fossil tissue using preserved DNA. However, the conditions required for DNA preservation in the fossil record are not understood. An organic geochemical study of fossil tissue and sediments has been undertaken at the Clarkia site to assess the preservation of other less labile compounds, such as leaf waxes, structural polysaccharides, cutins, lignins and chlorophyll pigments. Previous organic geochemical studies have developed an understanding of the behaviour of these compound classes in different environments. The relative behaviour of the compound classes and the preservation of individual compounds within each class can therefore help in the interpretation of the biogeochemistry of this site which may in turn shed light on the reported preservation of fossil DNA.

Leaf waxes are preserved but a selective loss of long chain esters has occurred, and microbial degradation products of triterpenoids have been identified. Structural polysaccharides and cutins have been lost from the leaf tissues. A highly resistant aliphatic polymer is preserved in the mesophyll and epidermal regions of the leaves, with lignin identified in leaf vein tissues. Various degradation products of chlorophyll have also been identified. The organic geochemical results are all consistent with microbial degradation within the leaf tissues and sediment. Excellent morphological preservation is not accompanied by mutual chemical preservation. The survival of DNA in this environment is extremely surprising. However, preservation of plant polyphenols may provide an answer to this anomaly. 